Gut, 1985, 26, 683-688

\title{
Autonomic regulation of postprandial plasma somatostatin, gastrin, and insulin
}

\author{
M R LUCEY, J A H WASS, P FAIRCLOUGH, J WEBB, S WEBB, \\ $S$ MEDBAK, AND L H REES
}

From the Departments of Gastroenterology, Endocrinology and Chemical Endocrinology, St Bartholomew's Hospital, London

SUMmARY To evaluate the neural regulation of postprandial somatostatin release we studied the effect of blockade of (a) alpha-adrenergic and beta-adrenergic and (b) cholinergic receptors on the plasma somatostatin, gastrin and insulin responses to a standard meal in two groups of five fasting healthy male volunteers. Thymoxamine $(0.1 \mathrm{mg} / \mathrm{kg}$ iv over two minutes then $10 \mathrm{mg} / \mathrm{hour}$ for two hours) and propranolol $(0.15 \mathrm{mg} / \mathrm{kg}$ iv over two minutes, then $0.75 \mathrm{mg} / \mathrm{kg} / \mathrm{hour}$ for two hours) were started just before eating while atropine $(0.04 \mathrm{mg} / \mathrm{kg} / \mathrm{im})$ was given at 15 minutes on completion of the meal. There was a prompt and sustained rise in plasma somatostatin after a control meal in all experiments. This rise was arrested by atropine but not altered by either thymoxamine or propranolol. The plasma gastrin response to a meal was moderately enhanced by thymoxamine and markedly enhanced by atropine. Postprandial insulin release was not affected by alpha- or beta-adrenergic blockade but was abolished by atropine. The effect of atropine on the postprandial plasma somatostatin rise might have been mediated through reduction in gastric acidity or delay in gastric emptying. Hence we gave five fasting male volunteers an intraduodenal infusion of fat emulsion ( 25 calories in 30 minutes) on two occasions both alone and after atropine. Plasma somatostatin rose during the fat infusion alone and this rise was abolished by atropine. These data suggest that (a) cholinergic but not adrenergic mechanisms are important modulators of plasma somatostatin release after orally ingested and intraduodenally infused nutrients (b) atropine abolishes plasma somatostatin release independently of its effects on gastric acidity and motility and (c) are consistent with the hypothesis that atropine potentiates postprandial gastrin release through reduction of somatostatin mediated inhibition.

Plasma somatostatin levels rise after a mixed meal in man. ${ }^{1}$ Although the site of origin of postprandial plasma somatostatin in man is uncertain, the stomach, pancreas, and upper small gut are the most likely sources. The neural mechanisms which control postprandial release of somatostatin in man are unknown. There is strong evidence, however, of adrenergic and cholinergic modulation of basal and stimulated release of somatostatin both in vitro and in vivo. Samols and Weir report that somatostatin release from isolated perfused canine pancreas was stimulated by beta-adrenergic agonists and inhibited by alpha-adrenergic agonists. ${ }^{2}$ Similarly, betaadrenergically mediated stimulation of the

Address for correspondence: Dr M R Lucey, The Liver Unit, Kings College Hospital, Denmark Hill, London SE5 8RX.

Received for publication 13 August 1984 somatostatin release has been postulated in the isolated rat stomach. ${ }^{3}$ Boden et al found that beta-adrenergic agonists raised portal and arterial plasma somatostatin in the intact dog, while alphaadrenergic agonists suppressed somatostatin release. ${ }^{4}$ Acetylcholine stimulates gastric and pancreatic somatostatin release in vivo in the dog. ${ }^{5}$ Atropine reduces the gastric and pancreatic somatostatin response to the gastric phase of a meal in dogs. ${ }^{6}$

The present study was designed to investigate autonomic control of release of plasma somatostatin by food in man. The study comprised three parts. In part 1 we studied the effect of alpha-adrenergic blockade and beta-adrenergic blockade separately on postprandial release of plasma somatostatin. In part 2 we studied the effect of cholinergic blockade 
on postprandial plasma somatostatin, and as we will describe, the postprandial rise was arrested. Because this alteration might have been mediated by reduction in gastric acidity, or delay in gastric emptying, in part 3 we proceeded to study the effect of a prior bolus of atropine on the plasma somatostatin response to an intraduodenal infusion of fat - a potent stimulus of plasma somatostatin release in $\operatorname{man}^{7}$ which is unlikely to be affected by changes in gastric acidity or motility.

\section{Methods}

\section{SUBJECTS}

Fifteen male volunteers, mean age 23 years (range 22-29 years), were within $10 \%$ of their ideal body weight and taking no medication. None had a history of endocrine, gastrointestinal, or renal disease. ${ }^{1}$ Alpha- and beta-adrenergic blockade: five subjects received on three separate occasions a standard breakfast ( $67 \mathrm{~g}$ carbohydrate, $17 \mathrm{~g}$ protein, $20 \mathrm{~g}$ fat, 560 calories, eaten over 15 minutes) plus a continuous intravenous infusion of either (a) normal saline, (b) thymoxamine $0 \cdot 1 \mathrm{mg} / \mathrm{kg}$ for two minutes, then $10 \mathrm{mg} / \mathrm{h}$ for two hours, or (c) propranolol 0.15 $\mathrm{mg} / \mathrm{kg}$ for two minutes, then $0.75 \mathrm{mg} / \mathrm{kg} / \mathrm{h}$ for two hours, each starting just before eating. ${ }^{2}$ Cholinergic blockade: five subjects were each given a standard breakfast eaten over 15 minutes on two occasions followed by an intramuscular bolus injection at 15 minutes of either saline or atropine $(0.04 \mathrm{mg} / \mathrm{kg})$. On a third occasion, each subject received intramuscular atropine alone. ${ }^{3}$ On two occasions a further five subjects were intubated with a fine bore flexible oroduodenal tube with its tip positioned in the second part of the duodenum with radiographic control and given a continuous infusion of fat emulsion, for 30 minutes $(12.5 \mathrm{ml} 20 \%$ Intralipid, KabiVitrum) made up to $125 \mathrm{ml} \mathrm{pH} 6$ containing 25 calories. On one occasion an intramuscular injection of atopine $(0.04 \mathrm{mg} / \mathrm{kg})$ was given prior to starting the intraduodenal infusion. All experiments were started at 8.30 am after an overnight fast. The procedures were separated by at least one week and carried out in random order. Blood for hormone assay was taken through an indwelling needle. Samples for hormone estimation were taken into lithium heparin tubes containing $10000 \mathrm{KIU}$ aprotonin, centrifuged at $4^{\circ} \mathrm{C}$ and separated. The plasma was frozen immediately and stored at $-20^{\circ} \mathrm{C}$ until assay. These studies were approved by the district ethical committee of Saint Bartholomew's Hospital. All subjects gave fully informed consent.

ASSAYS

Blood glucose was measured by the neocuproine method (Technicon). Plasma somatostatin, ${ }^{8}$ insulin ${ }^{9}$ and gastrin ${ }^{10}$ were measured by radioimmunoassay as previously described. All samples from each individual subject were included in the same assay. Somatostatin was extracted using Vycor glass; $I^{125}$ Tyrosine-somatostatin (4 pg/tube) was used as a tracer, together with a highly specific rabbit antisomatostatin anti-serum (1 in 150000$)$ which gives a sensitivity of $10 \mathrm{pg} / \mathrm{ml}$ plasma. The basal somatostatin levels recorded in part 3 differed from those in parts 1 and 2 . This was due to a newly prepared somatostatin standard solution which gave higher numerical values.

\section{STATISTICS}

Results are expressed as mean \pm 1 SEM. The Student's $t$ test for paired data was used and $\mathrm{p}<0.05$ considered significant.

\section{Results}

\section{ADRENERGIC BLOCKADE}

Systemic effects

There were no consistent changes in pulse rate or blood pressure during or after an infusion of thymoxamine. The pulse rate fell in all subjects with the infusion of propranolol from a mean basal rate of $70 \pm 3$ beats per minute to a nadir of $56 \pm 3$ beats per minute. $(\mathrm{p}<0 \cdot 01)$.

\section{Responses to a meal}

Plasma glucose rose postprandially in all three experiments to respective peak values of $6.4 \pm 0 \cdot 6$ $\mathrm{mU} / \mathrm{l}$ (saline) $6.8 \pm 0.5 \mathrm{mU} / 1$ (thymoxamine) and $6 \cdot 40 \pm 0.3 \mathrm{mU} / 1$ (propranolol). There were no significant differences at any time point.

\section{Somatostatin (Fig. 1)}

The basal plasma somatostatin concentrations were similar for each of the three experiments, the combined mean being $18 \pm 1 \mathrm{pg} / \mathrm{ml}$. There was a prompt and sustained rise in plasma somatostatin after the meal on each occasion to peaks of $48 \pm 9$ $\mathrm{pg} / \mathrm{ml}$ (saline) $(\mathrm{p}<0.02$ compared with basal); $57 \pm 10$ $\mathrm{pg} / \mathrm{ml}$ (thymoxamine) $(\mathrm{p}<0.02$ compared with basal) and $54 \pm 10 \mathrm{pg} / \mathrm{ml}$ (propranolol) $(\mathrm{p}<0.01$ compared with basal). In the thymoxamine experiment the postprandial plasma somatostatin level significantly exceeded the saline control value at 150 minutes only, $57 \pm 10 \mathrm{pg} / \mathrm{ml}$ compared with $43 \pm 10 \mathrm{pg} / \mathrm{ml}(\mathrm{p}<0 \cdot 02)$. Propranolol caused no significant differences from the control responses at any time point.

\section{Gastrin}

There was a prompt and sustained rise in plasma 


\begin{tabular}{|l|}
\hline IV Infusion \\
Meal
\end{tabular}
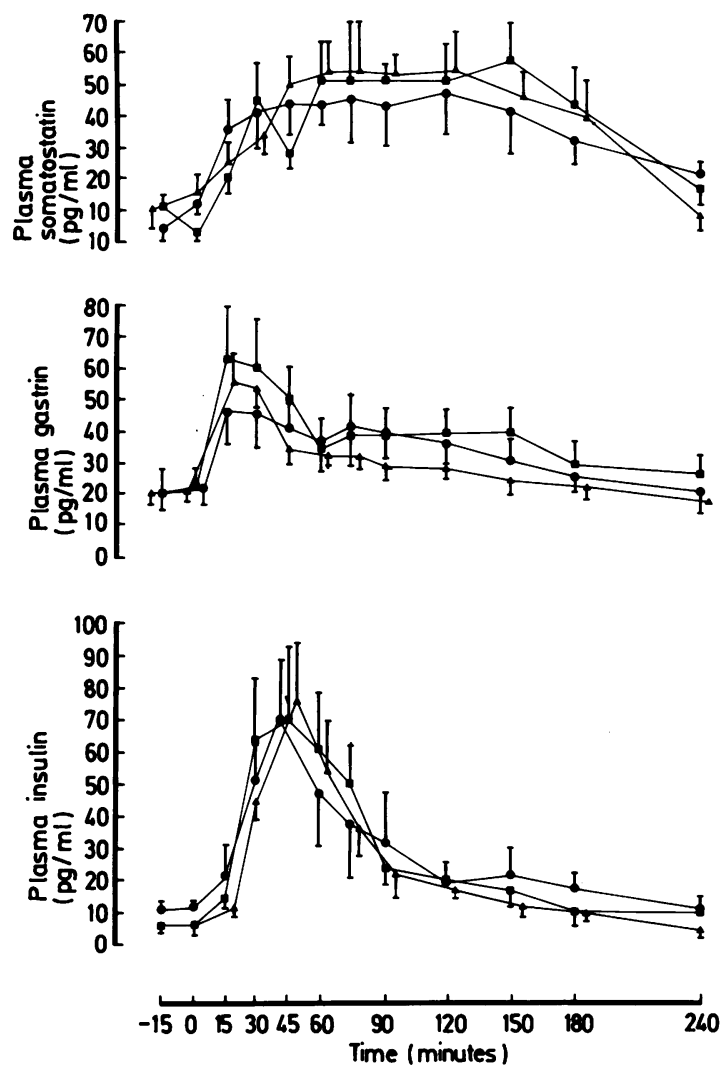

Fig. 1 Plasma somatostatin, plasma gastrin and plasma insulin in five subjects given a meal plus an intravenous infusion of saline (O); a meal plus intravenous thymoxamine (ם); a meal plus intravenous propranolol (A). Vertical bars are 1 SEM.

gastrin from a fasting level of $22 \pm 4 \mathrm{pg} / \mathrm{ml}$ to peaks at 15 minutes of $48 \pm 10 \mathrm{pg} / \mathrm{ml}$ (saline) $(\mathrm{p}<0.05$ compared with basal), $64 \pm 17 \mathrm{pg} / \mathrm{ml}$ (thymoxamine) $(\mathrm{p}<0.05$ compared with basal) and $55 \pm 11 \mathrm{pg} / \mathrm{ml}$ (propranolol) $(p<0.02$ compared with basal). Plasma gastrin concentrations during the thymoxamine experiment significantly exceeded those in the control experiment at 45 minutes $(p<0.05)$ and 180 and 240 minutes (both $p<0.02)$. The plasma gastrin responses to a meal plus propranolol significantly exceeded the control values at 15 minutes $(\mathrm{p}<0.02)$ but were significantly less than the control at 150 minutes $(\mathrm{p}<0.02)$.

\section{Insulin}

Plasma insulin concentrations rose to peak values of
$72 \pm 21 \mathrm{mU} / \mathrm{l}$ (saline), $70 \pm 20 \mathrm{mU} / \mathrm{l}$ (thymoxamine) and $77 \pm 18 \mathrm{mU} / \mathrm{l}$ (propranolol), respectively, each at 45 minutes and $p<0.05$ compared with basal. There were no significant differences between the plasma insulin levels in the control experiment and those during either alpha-adrenergic or beta-adrenergic blockade.

\section{CHOLINERGIC BLOCKADE}

Systemic effects

All subjects experienced dry mouth and tachycardia after atropine. The pulse rate rose from a basal rate of $70 \pm 3$ beats per minute to a peak of a $107 \pm 3$ beats per minute within 45 minutes of administration of atropine $(p<0 \cdot 01)$.

Responses to a meal (Fig 2)

\section{Somatostatin}

The fasting plasma somatostatin concentrations
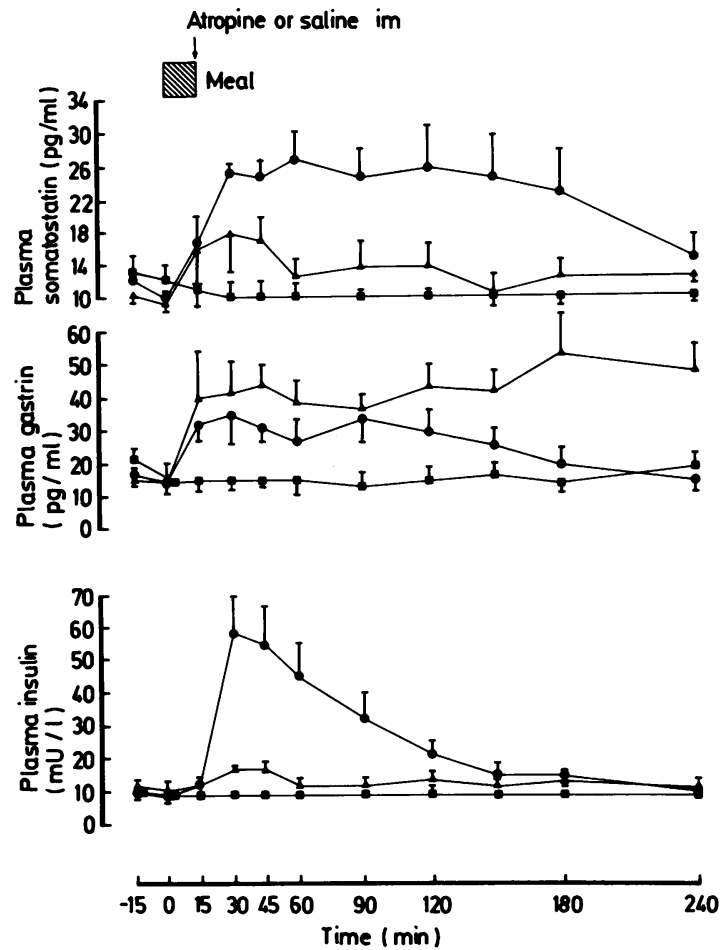

Fig. 2 Plasma somatostatin, plasma gastrin and plasma insulin in five subjects given a meal plus saline intramuscularly (O), a meal plus atropine intramuscularly $(\boldsymbol{\Delta})$ and atropine intramuscularly alone (घ). Vertical bars are 1 SEM. 
were similar in all three subjects, combined mean being $12 \pm 1 \mathrm{pg} / \mathrm{ml}$. There was a prompt and sustained rise in postprandial plasma somatostatin in the control experiment to a peak of $27 \pm 4 \mathrm{pg} / \mathrm{ml}$ at 60 minutes $(\mathrm{p}<0.02$ compared with basal). Atropine arrested the expected rise in plasma somatostatin when given 15 minutes after starting the meal. The reduction in plasma somatostatin reached significance at 60 minutes $(\mathrm{p}<0.01) 90$ minutes $(\mathrm{p}<0.02), 120$ minutes and 150 minutes (each $\mathrm{p}<0.05)$. After atropine alone the plasma somatostatin levels fell to the limits of detection of the assay.

\section{Gastrin}

There was a prompt and sustained rise in postprandial plasma gastrin concentrations during the control experiment to a peak at 30 minutes of $35 \pm 9 \mathrm{pg} / \mathrm{ml}(\mathrm{p}<0.02$ compared with basal) with the levels returning to baseline by 240 minutes. When the meal was followed by atropine, both the peak and duration of the plasma gastrin response was greater than in the saline control experiment, peak $54 \pm 12 \mathrm{pg} / \mathrm{ml}$ at 180 minutes $(\mathrm{p}<0.02$ compared with basal). The increase in the plasma gastrin response to a meal plus atropine compared with the control meal reached significance at 30 minutes $(\mathrm{p}<0.05)$, 45 minutes $(\mathrm{p}<0.01), 60$ minutes $(\mathrm{p}<0.05)$, and at all time points from 120 minutes to the end of the experiment. There was no change in plasma gastrin concentrations after atropine alone.

\section{Insulin}

Plasma insulin rose to a sustained peak of $57 \pm 13$ $\mathrm{mU} / \mathrm{l}$ at 30 minutes ( $\mathrm{p}<0.05$ compared with basal). This postprandial rise was abolished by atropine and the differences reached significance at 30,45 , and 60 minutes $(\mathrm{p}<0.02)$ and 90 minutes $(\mathrm{p}<0.05)$. Plasma insulin levels did not change after atropine alone.

\section{Intraduodenal infusion of fat (Fig. 3)}

\section{Somatostatin}

The basal somatostatin concentrations were similar in both experiments, the mean level being $50 \pm 6$ $\mathrm{pg} / \mathrm{ml}$. During the infusion of fat alone plasma somatostatin levels rose promptly to a peak of $112 \pm 22 \mathrm{pg} / \mathrm{ml}$ at 30 minutes $(\mathrm{p}<0.02$ compared with basal), and rapidly returned to basal levels after the completion of the infusion of fat. Before administration of atropine abolished this response and the differences between the atropine and control experiment reached significance at 30 minutes $(\mathrm{p}<0 \cdot 05)$. Plasma gastrin did not change after intraduodenal infusion of fat either alone or after atropine.

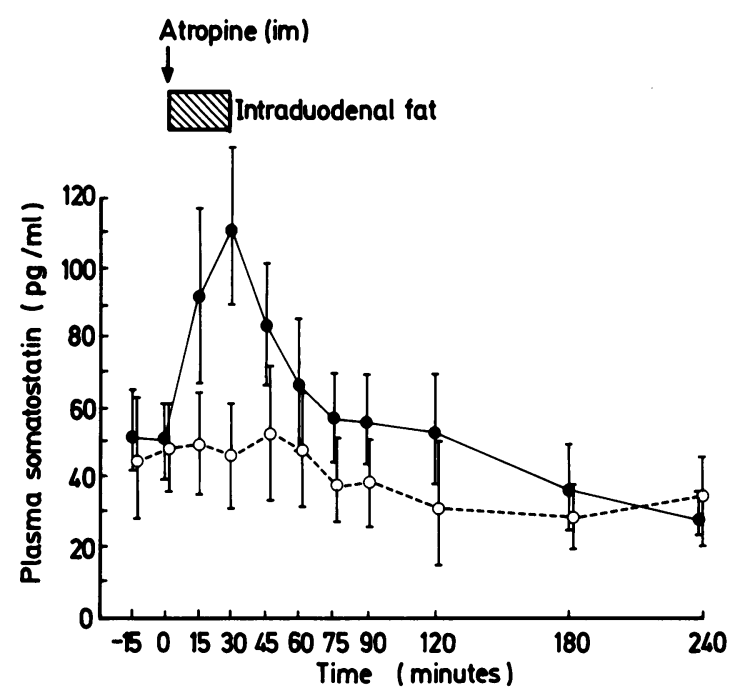

Fig. 3 Plasma somatostatin in five subjects given an intraduodenal infusion of fat emulsion $(12.5 \mathrm{ml} 20 \%$ Intralipid) both without $(\mathbf{O})$ and with $(\mathbf{\Delta})$ atropine intramuscularly. Vertical bars are 1 SEM.

\section{Discussion}

This study has shown in man that cholinergic mechanisms are important in mediating postprandial plasma somatostatin release, but failed to demonstrate such a role for adrenergic mechanisms. There is no doubt that the doses of propranolol and atropine were pharmacological, as marked and consistent changes in pulse rate occurred. Although objective evidence of alpha-adrenergic blockade during infusion of thymoxamine was not available, the dose used was $1 \times 10^{2}$ times greater than that reported to attenuate the peripheral vasoconstrictive effect of noradrenaline in normal subjects. ${ }^{11}$ There are a number of possible explanations for the failure to show a clear involvement of either alpha- or beta-adrenergically mediated control of postprandial plasma somatostatin release, as has been suggested from animal studies. ${ }^{2-4}$ These include differences between in vitro and in vivo models, species variation in responses and differing specificities of antibodies used in the assay of somatostatin. It is of interest that Epstein and Berelowitz failed to alter plasma somatostatin concentrations in man with infusion of isoprenaline or dopamine, while propranolol caused a slight decline in unstimulated plasma somatostatin. ${ }^{12} \mathrm{~A}$ further possible factor may be the selectivity of thymoxamine for alpha-1adrenoceptors. ${ }^{13}$ In the isolated perfused canine 
pancreas, however, somatostatin release is reduced by phenoxybenzamine which, like thymoxamine, also shows alpha-l-adrenoceptor selectivity. ${ }^{2}$

The action of atropine on postprandial circulating somatostatin in the present study may be mediated through direct cholinergic blockade. Alternatively, it may be the indirect result of some other effect of cholinergic blockade, such as reduction in gastric acid output or delay in gastric emptying. As atropine also abolished the plasma somatostatin response to an intradodenal infusion of fat, however, we suggest that its action in reducing the plasma somatostatin response to a luminal nutrient stimulus appears to be independent of its effects on gastric acidity or emptying, and is likely to be a direct result of cholinergic blockade. This contention is consistent with our data on the effect of intragastric and intraduodenal infusions of dilute hydrochloric acid on circulating somatostatin in man in which somatostatin concentrations were unchanged by intragastric acid infusions and rose moderatley only when grossly supraphysiological doses of acid were given intraduodenally. ${ }^{14}$ Thus acid per se is not a major stimulus of plasma somatostatin while the vagus nerve appears to directly mediate the release of plasma somatostatin after oral or intraduodenal nutrients. Similarly, vagotomy ${ }^{15}$ and autonomic neuropathy ${ }^{16}$ prevent the plasma somatostatin rise after insulin-induced hypoglycaemia.

The regulation of gastrin release in man is complex and there is evidence to suggest both betaand alpha-adrenergic modulation. Exogenous adrenaline stimulates gastrin release and this is inhibited by beta-blockade in man. ${ }^{17}$ Propranalol reduces the plasma gastrin response to gastric distension in man. ${ }^{18}$ Phentolamine, when given with atropine, but not when given alone increases the plasma gastrin response to this stimulus. ${ }^{18}$ The moderate increase in postprandial plasma gastrin during an infusion of thymoxamine but not propranolol in the present study suggests the participation of alpha-adrenergic mechanisms in postprandial gastrin release, but does not elucidate further the contribution if any of beta-adrenergic mechanisms.

Atropine augmented the plasma gastrin response to food confirming the work of other investigators. ${ }^{19}{ }^{20}$ Atropine has been reported to enhance gastrin release after gastric distension ${ }^{21}$ and sham feeding. ${ }^{22}$ The mechanism of cholinergically mediated inhibition of gastrin release in man is unknown, but Feldman et al have questioned whether somatostatin could be an intermediate in this pathway. 22 In the isolated rat stomach infusion of anti-somatostatin antiserum stimulates gastrin release and this may be a cholinergic phenomenon. ${ }^{23}$ Hence Saffouri et al postulate that somatostatin exerts a continuous restraint on gastrin release. $^{23}$ Our data are consistent with the hypothesis that atropine augments the postprandial release of gastrin by reduction in somatostatin mediated inhibition.

The failure of thymoxamine to alter the postprandial release of plasma insulin differs from previous reports in man of enhancement by phentolamine of insulin release following intravenous or intraduodenal glucose,${ }^{24} 25$ or intravenous arginine. ${ }^{26}$ As phentolamine is an antagonist at both alpha-1 and alpha-2adrenoceptors, receptor selectivity may account for this discrepancy. Indeed Nakadate et al have suggested that in mice alpha- 2 rather than alpha-1adrenoceptors influence plasma insulin levels. ${ }^{27}$ Propranolol has been reported to reduce the plasma insulin response to an oral or intraduodenal glucose load in man. ${ }^{24} 25$ It is not clear why beta-adrenergic blockade had no effect on plasma insulin responses to a meal in the present study. The abolition by atropine of the postprandial rise in plasma insulin is in keeping with previous reports of inhibition by atropine of insulin secretion after an oral glucose load in man. ${ }^{28}$

Drs Lucey and Medbak were supported by the Joint Research Board of St Bartholomew's Hospital. This work was presented in part to the American Gastroenterology Association (1983). The authors thank Dr A M Dawson for expert advice.

\section{References}

1 Wass JAH, Penman E, Dryburgh JR et al. Circulating somatostatin after food and glucose in man. Clin Endocrinol 1980; 12: 569-74.

2 Samols E, Weir G. Adrenergic modulation of pancreatic $A$ B and D cells: adrenergic suppression and adrenergic stimulation of glucagon secretion in the perfused dog pancreas. $J$ Clin Invest 1979; 63: 230-8.

3 Goto Y, Berelowitz M, Frohman LA. Effect of catacholamines on somatostatin secretion by isolated perfused rat stomach. Am J Physiol 1981; 240: E274-8.

4 Boden G, Masur RW, Sattler MA, Martin JS, Tansey MF, Owen OE. Adrenergic control of somatostatin release. Endocrinology 1982; 111: 1166-72.

5 Schusdziarra V, Stapelfeldt W, Klier M, Pfeiffer ET. Effect of acetylcholine on the release of pancreatic and gastric somatostatin-like immunoreactivity in normal, chemically sympathectomised and indomethacintreated dogs. Hepatogastroenterology 1982; 29: 153-6.

6 Schusdziarra V, Rouiller D, Harris V, Unger RH. Gastric and pancreatic release of somatostatin-like 
immunoreactivity during the gastric phase of a meal. Effects of truncal vagotomy and atropine in the anaesthetized dog. Diabetes 1979; 28: 658-63.

7 Lucey MR, Fairclough PD, Wass JAH et al. Response of circulating somatostatin, G.I.P. insulin and gastrin to intraduodenal infusion of nutrients in normal man. Clin Endocrinol 1984; 21: 209-17.

8 Penman E, Wass JAH, Lund A et al. Development and validation of a specific radioimmunoassay for somatostatin in human plasma. Ann Clin Biochem 1979; 16: 15-25.

9 Morgan CR, Lazarow A. Immunoassay of insulin: two antibody system. Plasma insulin levels in normal subdiabetic and diabetic rats. Diabetes 1963; 12: 115-26.

10 Yalow RS, Berson SA. Radioimmunoassay of gastrin. Gastroenterology 1970; 58: 1-14.

11 Collier JG, Nachev Ch, Robinson BF. Comparison of blockade at alpha-adrenoceptors by thymoxamine and phentolamine in peripheral arteries and veins in man. Br J Pharmacol 1972; 44: 294-300.

12 Epstein S, Berelowitz M. The lack of adrenergic effects of somatostatin-like immunoreactivity in normal man. Neuropeptides 1981; 2: 53-8.

13 Drew GM. Effects of alpha-adrenoceptor agonists and antagonists on pre and post synaptically located adrenoceptors. Eur J Pharmacol 1976; 36: 313-20.

14 Lucey MR, Wass JAH, Fairclough PD et al. Does gastric acid release plasma somatostatin in man? Gut 1984; 25: 1217-20.

15 Glaser B, Vinik AI, Valtyason G, Zoghlin G. Truncal Vagotomy abolishes the somatostatin response to insulin-induced hypoglycaemia in man. $J$ Clin Endocrinol Metab 1981; 52: 823-5.

16 Hilsted J, Madsbad S, Krarup T et al. No response of pancreatic hormones ot hypoglycaemia in diabetic autonomic neuropathy. J Clin Endocrinol Metab 1982; 54: 813-9.

17 Stadil F, Rehfeld JF. Release of gastrin by epinephrine in man. Gastroenterology 1973; 65: 210-15.

18 Peters MN, Walsh J H, Ferrari J, Feldman M. Adrenergic regulation of distension-induced gastrin release in humans. Gastroenterology 1982; 82: 659-63.

19 Walsh J H, Yalow R, Berson S A. Effect of atropine on plasma gastrin response to feeding. Gastroenterology 1971; 60: 16-21.

20 Korman MG, Sovery C, Hansky J. Effect of food on serum gastrin evaluated by radioimmunoassay. Gut 1971; 12: 619-24.

21 Schiller, LR, Walsh JH, Feldman M. Distensioninduced gastrin release. Effects of luminal acidification and intravenous atropine. Gastroenterology 1980; 78: 912-7.

22 Feldman M. Walsh JH. Acid inhibition of sham feeding stimulated gastrin release and gastrin acid secretion. Effect of atropine. Gastroenterology 1980; 78: 772-6.

23 Saffouri B, Weir GC, Bitar KN, Makhlouf GM. Gastrin and somatostatin secretion by perfused rat stomach: functional linkage of antral peptides. $\mathrm{Am} \mathrm{J}$ Physiol 1980; 238: G495-501.

24 Buse MG, Johnson AH, Kuperminc D, Buse G. Effect of alpha-adrenergic blockade on insulin secretion in man. Metabolism 1970; 19: 219-25.

25 Flaten O, Sand T, Myren J. The effect of adrenergic blockade on insulin release in man. Acta Physiol Scand 1981; 113: 415-6.

26 Imura $\mathrm{H}$, Kato Y, Ikeda M, Morimoto M, Yawata M. Effect of adrenergic blocking or stimulating agents on plasma growth hormone, immunoreactive insulin and blood free fatty acid levels in man. J Clin Invest 1971; 51: 1069-79.

27 Nakadate T, Nakaki T, Muraki T, Kato RY. Regulation of plasma insulin level by alpha ${ }_{2}$-adrenergic receptors. Eur J Pharmacol 1981; 65: 421-4.

28 Henderson JR, Jefferys DB, Jones RR, Stanley D. The effect of atropine on insulin release caused by oral and intravenous glucose in human subjects. Acta Endocrinol 1976; 83: 772-80. 